\title{
The relationship of children sensitized to peanut and parental asthma in Study Asthma Genes and the Environment (SAGE)
}

\author{
Henry Huang ${ }^{1,4^{*}}$, Rishma Chooniedass ${ }^{4}$, Anita Kozyrskyj ${ }^{2,3,4}$, Allan Becker $^{4}$ \\ From AllerGen NCE Inc.'s Fifth Annual Research Conference: Innovation from Cell to Society \\ Québec City, QC, Canada. 7-9 February 2010
}

\section{Background}

Children with asthma most often have associated allergy, and peanut allergy with asthma is more common in children whose parents have asthma. It is not clear how common peanut allergy is among these children. The St. John's cohort, India has found $6.2 \%$ peanut sensitivity children whose mothers have asthma. Children are at greater risk for severe life threatening reactions and hospitalization.

\section{Materials and methods}

The SAGE cohort is a study of children born in 1995 in Manitoba. We created a nested case-control cohort of 723 children for asthma and allergy at 8 years of age. Atopy was defined as having at least one positive skin test, to common inhalants and to peanut (wheal diameter $\geq 3 \mathrm{~mm}$.) Chi-square test and Fisher's exact test was applied, the likelihood (odds ratio, OR) of parental asthma of non-peanut allergic children compared to parental asthma of peanut sensitized children was determined.

\section{Results}

In the cohort, 220 (30.4\%) parents were diagnosis with asthma. 718 children skin tested, 333 (46.4\%) were atopic with $42(5.8 \%)$ sensitized to peanut. Peanut sensitized children are more likely to have asthma $(\mathrm{OR}=2.8$, 95\%CI 1.5-5.2). Among 246 (34.1\%) children with asthma, 6 (2.5\%) children who had a parent with asthma were sensitized to peanut $(\mathrm{OR}=0.8,95 \% \mathrm{CI}$ 0.3-1.9) when compared with children whose parents did not have asthma.

'Department of Statistics, University of Manitoba, Winnipeg, Manitoba, R3E 3P4, Canada

Full list of author information is available at the end of the article

\section{Conclusion}

Peanut allergy is more common in children who have asthma, but there is not an additional significant association with parental asthma. Diagnosing peanut allergy in an early childhood is an early marker for increased asthma risk.

\section{Author details \\ 'Department of Statistics, University of Manitoba, Winnipeg, Manitoba, R3E 3P4, Canada. ²Department of Community Health Sciences, University of Manitoba, Winnipeg, Manitoba, R3E 3P4, Canada. ${ }^{3}$ Department of Pediatrics, University of Alberta, Edmonton, Alberta, T6G 2J3, Canada. ${ }^{4}$ Section of Allergy and Clinical Immunology, University of Manitoba, Winnipeg, Manitoba, R3E 3P4, Canada.}

Published: 26 November 2010

doi:10.1186/1710-1492-6-S3-P33

Cite this article as: Huang et al:: The relationship of children sensitized to peanut and parental asthma in Study Asthma Genes and the Environment (SAGE). Allergy, Asthma \& Clinical Immunology 2010 6(Suppl 3):P33.

Submit your next manuscript to BioMed Central and take full advantage of:

- Convenient online submission

- Thorough peer review

- No space constraints or color figure charges

- Immediate publication on acceptance

- Inclusion in PubMed, CAS, Scopus and Google Scholar

- Research which is freely available for redistribution 